\title{
Hemiplejik Ağrılı Omuzda Supraskapular Sinir Blokajı ve Glenohumeral Eklem Enjeksiyonu: Ağrı ve Özürlülük Üzerindeki Etkilerinin Karșılaștırılması
}

\section{Suprascapular Nerve Block and Glenohumeral Injection in Hemiplegic Shoulder Pain: To Compare the Effectiveness on Pain and Disability}

\author{
Ayşegül TUBAY, Serpil BAL, Korhan Barış BAYRAM, Hikmet KOÇYIĞIT, Alev GÜRGAN \\ Atatürk Eğitim ve Araştırma Hastanesi 2. Fizik Tedavi ve Rehabilitasyon Kliniği, Izmir, Türkiye
}

Özet

Amaç: Çalışmanın amacı hemiplejik omuz ağrısı olan hastalarda supraskapular sinir blokajı (SSS) ve glenohumeral (GH) eklem enjeksiyonunun etkinliklerini karşılaştırmaktır.

Gereç ve Yöntem: Çalışmaya en az 3 aydır hemiplejik omuz ağrısı olan toplam 36 hasta alındı. Hastalar 2 gruba randomize edildi. Birinci gruba SSS blokajı, ikinci gruba ise GH ekleme steroid enjeksiyonu uygulandı. Hastalar tedavi öncesi, tedaviden hemen sonra (30. dakika), 2. hafta ve 3. ayda değerlendirildi. Değerlendirmede VAS ile istirahat, gece ve hareket sırasındaki ağrı yoğunlukları ve omuz eklem hareket açıklıkları saptandı. Ayrıca üst ekstremite özürlülük durumu fonksiyonel bağımsızlık ölçeği (FBÖ) ile değerlendirildi.

Bulgular: Enjeksiyon sonrasında her iki grupta da tedavi sonrası-hemen, 2. hafta ve 3. ayda istirahat, hareket ve gece ağrısında anlamlı azalma saptandı. Değişim skorları her iki grupta da benzerdi. Bunun yanında her iki enjeksiyon grubunda da eklem hareket açıklıkları ve FBÖ skorlarında tedavi sonrası 2. hafta ve 3. ayda anlamlı düzelmeler saptanırken bu düzelmeler iki grup arasında benzerdi.

Sonuç: Hemiplejik omuz ağrısının tedavisinde GH eklem enjeksiyonu ve SSS blokajının ağrı ve foksiyonel durumlar açısından üç aya varan düzelme sağlamakla birlikte birbirlerine üstünlükleri yoktur. Türk Fiz Tıp Rehab Derg 2012;58:299-303.

Anahtar Kelimeler: Glenohumeral enjeksiyon; hemipleji; omuz ağrısı; supraskapular sinir blokajı

\section{Summary}

Objective: The aim of this study was to compare the effectiveness of glenohumeral $(\mathrm{GH})$ joint injection and suprascapular nerve block (SNB) in patients with hemiplegic shoulder pain.

Materials and Methods: Thirty-six patients with shoulder pain lasting for at least 3 months were randomized into two groups in which SNB was applied in the first and $\mathrm{GH}$ joint steroid injection in the second group. All patients were evaluated before treatment, after 30 minutes, second week and third month after the treatment. Pain at rest, with motion and nocturnal pain were determined by the visual analogue scale. Shoulder joint range of motion was recorded for all patients. Disability status was assessed using the Functional Independence Measure (FIM).

Results: There was a significant decrease in VAS scores for pain at rest, night and activity immediately after, at the second week and at the third month after the treatment in both groups. Change scores were similar in both groups.

Conclusion: Although, both GH joint injection and SNB reduced pain and improved functional status at upto 3 months, there was no superiority of the one over the other. Turk J Phys Med Rehab 2012;58:299-303.

Key Words: Glenohumeral injection; hemiplegia; shoulder pain; suprascapular nerve block 


\section{Giriş}

Hemiplejik omuz ağrısı (HOA) inme sonrası gelişen komplikasyonlar arasında yer alır, görülme sıklığı nadir olmayıp, literatürde \%16-84 arasında değişen oranlarda bildirilmiştir (1). HOA inmeyi takiben sıklıkla ilk hafta içinde görülmekle birlikte, ilk yıl içinde herhangi bir zamanda gelişebilir (2). Hemiplejik hastaların rehabilitasyonunda, eşlik eden HOA varlığı hastaların gerek hastanede kalış sürelerinin uzaması gerekse rehabilitasyon kazanımlarını negatif yönde etkilemesi açısından önemli bir sorundur. Etiyolojisinde glenohumeral eklem subluksasyonu, donuk omuz, sıkışma sendromu, rotator manşon yırtıkları, kompleks bölgesel ağrı sendromu, brakiyal pleksus yaralanmaları, talamik ağrı ve heterotopik ossifikasyon yer alır (3). Omuzun kompleks yapısı nedeniyle HOA nedenleri multifaktöryeldir ve her zaman tek başına bir neden belirlemek zordur. Nörolojik hasara bağlı olarak oluşan immobilizasyon ve kas tonusu değişiklikleri ve uygun olmayan egzersiz, pozisyonlama, hasta transferi sırasında eklem ve eklem çevresindeki yumuşak dokuların hasar görmesi HOA'ya neden olan faktörlerdir (4).

HOA tedavisinde enjeksiyonlar da dahil olmak üzere fizik tedavi modaliteleri ve egzersizleri de içeren farklı tedavi yöntemleri mevcuttur. Literatürde HOA'nın tedavisinde enjeksiyonların etkinliğini değerlendiren yeterli sayıda çalışma bulunmamaktadır (5-7).

Supraskapular sinir omuzun duysal innervasyonunu sağlar. Supraskapular sinir blokları romatoid artrit, donuk omuz ve rotator manşon lezyonlarında ağrıyı ortadan kaldırmak amacıyla kullanılmaktadır. Ancak HOA'da tedavi etkinliğini değerlendiren az sayıda çalışma vardır. Lee ve ark. (6) tarafından sadece üç hasta ile yapılan çalışmada, supraskapular sinir blokajının hastaların ağrılarında tam bir düzelme sağlamadığı bildirilmiştir. Yakın zamanda yayınlanmış diğer bir çalışmada ise hem supraskapular sinir blokajının hem de intraartiküler steroid enjeksiyonunun HOA'da etkin olduğu, ancak birbirlerine üstünlüklerinin olmadığı gösterilmiştir (8).

$\mathrm{Bu}$ çalışmamızda hemiplejik hastalarda, hemiplejik taraftaki omuz ağrısı ve özürlülüğün tedavisinde supraskapular sinir blokajı ile glenohumeral eklem enjeksiyonunun etkinliğini karşılaştırmayı amaçladık.

\section{Gereç ve Yöntem}

Çalışmaya Fiziksel Tıp ve Rehabilitasyon kliniğine rehabilitasyon amacı ile yönlendirilmiş, en az 3 aydır omuz ağrısı ve/veya hareket kısıtlıı̆̆ı olan 36 hemiplejik hasta alındı. HOA istirahatteki omuz ağrısı ve/veya aktif ve pasif omuz hareketleriyle ağrı olması olarak kabul edildi. Hastalar poliklinik sıra numarasına göre basit rastgele yöntemle 2 gruba randomize edildiler: Supraskapular sinir (SSS) blokajı ve glenohumeral $(\mathrm{GH})$ eklem enjeksiyonu.

Çalışmaya alınan hastalardan "gönüllü bilgilendirme formu" ve yerel etik kurul onayı alındı. Çalışmaya en az 4 ay önce hemipleji gelişen, hemiplejik tarafta en az 3 aydır omuz ağrısı olan ve18 yaş üstü olan hastalar alındı.
Birden fazla inme atağı geçirmiş olanlar, son 6 ayda omuza yönelik fizik tedavi ve/veya enjeksiyon öyküsü olanlar, son 3 ayda travma geçirenler, malignite öyküsü olanlar, servikal disk patolojisi olanlar (klinik muayene ve radyolojik tetkik ile), kooperasyonu kısıtlı olanlar ve mental problemi olanlar, steroid kullanımı için kontrendikasyonu bulunanlar (diyabet, ileri derecede osteoporoz), warfarin kullananlar, kullanılan lokal anestezik (prilokain) maddeye karşı aşırı duyarııı̆ı olanlar çalışma dışı tutuldular.

Hastaların ayrıntılı öykülerinde yaş, cinsiyet, eğitim düzeyleri, inmenin oluş tarihi, inmenin natürü (iskemik, hemorajik), hemipleji tarafı (sağ/sol) ve hastaların dominant tarafları sorgulandı. İnme etiyolojisi, inme sonrası geçen süre dosya kayıtlarından elde edildi. Omuz ağıısının başlangıç tarihi hasta ve/veya hasta yakınlarına sorularak belirlendi. Inmeye eşlik eden hastalık varlığı ve kullandıkları ilaçları kaydedildi. Tedavi öncesi ve sonrası analjezik kullanıp kullanmadığı sorgulandı.

Analjezik kullanımı varlığı evet, yokluğu hayır olarak tanımlandı. Ayrıca Vizüel Anolog Skala (VAS) üzerinde hastanın ve hekimin ayrı ayrı memnuniyet dereceleri işaretlenerek belirtildi.

Tüm hastaların kas iskelet sistemi ve nörolojik muayeneleri yapıldı. Hastaların ağrılı taraftaki omuz manyetik rezonans görüntleme (MRG) ve karşılaştırmalı olarak antero-posterior omuz grafileri çekildi. Subakromial sıkışma sendromunun evreleri için Zlatkin ve ark. (9) tarafından hazırlanan radyolojik sınıflama kullanıldı. Zlatkin MRG evrelemesinde rotator kaf tendon patolojileri dört evrede değerlendirilmiştir:

Tip 0: Tendon sinyal intensitesi ve morfolojisi normaldir.

Tip 1: Tendon sinyal intensitesi artmıştır, ancak morfolojisi normaldir

Tip 2: Tendon sinyal intensitesi artmıştır, ancak morfolojisi bozulmuştur. Tendonun incelmesi ve konturlarının düzensizliği morfolojik bozukluk olarak tanımlanır.

Tip 3: Tendon normal trasesinde devamsızlık görülür. Tendonda devamsızlık görülen bölge, T2 ağırıklı kesitlerde tipik olarak hiperintens sinyal verir.

Akromion tipinin saptanmasında Bigliani ve ark. (10) tarafından hazırlanan sınıflama kullanıldı

Tip 1: Düz

Tip 2: Kıvrık

Tip 3: Çengel

Omuz eklem hareket açıklığı (EHA) ölçümleri el gonyometresi ile ağrılı omuz fleksiyon, ekstansiyon, abduksiyon, adduksiyon, internal ve eksternal rotasyon ölçüldükten sonra kaydedildi. Ölçümler hasta sırt üstü yatar pozisyonda iken yapıldı. İç ve dış rotasyonlar omuz 90 derece abduksiyonda ve dirsek fleksiyon pozisyonunda ölçüldü.

Supraskapular sinir blokajı Shanahan ve ark. (11) tarafından tanımlanan yöntemle uygulandı. Yüzey anatomisi ile blokaj yapılacak bölge belirlendi. Buna göre hasta oturur pozisyonda iken, skapulanın inferior açısından skapula spinasına bir dik çizilerek kesişme noktası belirlendi. Bu kesişme noktasının $2 \mathrm{~cm}$ laterali (skapulanın üst-dış kadranında yer alacak şekilde) enjeksiyon 
noktası olarak belirlendi (Şekil 1). Steril şartlar hazırlandıktan sonra

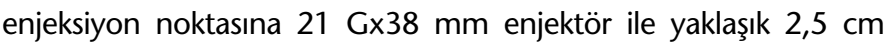
derinliğe girilerek $\% 2$ prilokain $(7 \mathrm{ml})$ ve $40 \mathrm{mg}$ triamsinolon asetonat'tan (1 ml) oluşan karışım enjekte edildi.

Glenohumeral eklem enjeksiyonu posterior yaklaşımla akromionun posteriolateral köşesinin $2-3 \mathrm{~cm}$ inferiorundan girilerek anteriora korakoid proses yönünde ilerletilerek uygulandı. Yüzey anatomisi ile enjeksiyon yapılacak bölge belirlendi. Hasta oturur pozisyonda iken belirlenen noktaya steril şartlar hazırlandıktan sonra $21 \mathrm{G} \times 38 \mathrm{~mm}$ enjektör ile girilerek \%2 prilokain $(1 \mathrm{ml})$ ve $40 \mathrm{mg}$ triamsinolon asetonat'tan (1 ml) oluşan karışım enjekte edildi (Şekil 2).

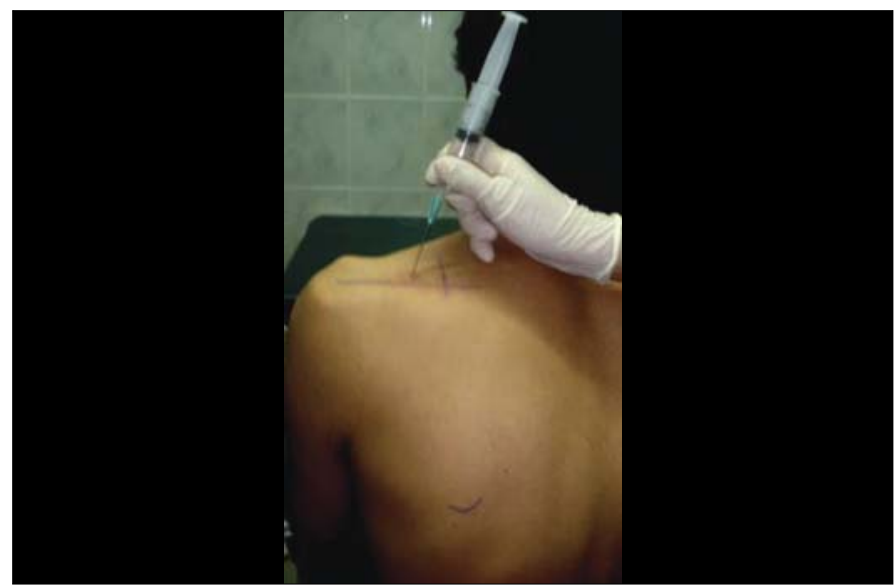

Şekil 1. Supraskapular sinir blokajının uygulanması.
Özürlülük durumu Fonksiyonel Bağımsızlık Ölçeği (FBÖ) kullanılarak yapıldı (12)

Çalışmaya alınan tüm hastaların; tam kan sayımı, rutin biyokimya, Eritrosit Sedimentasyon HIZI (ESR) ve serum C-Reaktif Protein (CRP) değerleri istendi.

Verilerin değerlendirilmesinde SPSS 15.0 paket programı (SPSS, Chicago, IL, USA) kullanıldı. Hasta özelliklerinin belirlenmesinde tanımlayıcı istatistikler, SSS blokajı uygulanan ve GH eklem enjeksiyonu uygulanan hasta gruplarının karşılaştııılmasında MannWhitney $U$ testi ve ki-kare testleri, grup içi karşılaştırmalarda Wilcoxon Signed Ranks testi, grup içi tekrarlayan ölçümlerin

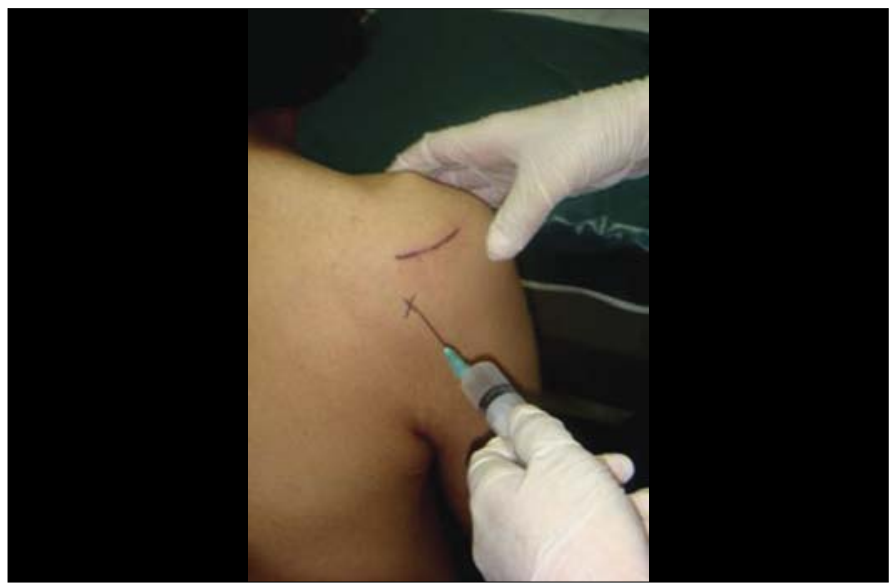

Şekil 2. GH eklem enjeksiyonunun uygulanması.

\section{Tablo 1. Bulgular-Demografik özellikler.}

\begin{tabular}{|c|c|c|c|c|}
\hline & & $\begin{array}{c}\text { SSS blokaj } \\
\text { Grubu }(n=18)\end{array}$ & $\begin{array}{l}\text { GH Enjeksiyon } \\
\text { Grubu }(n=18)\end{array}$ & $p *, \dagger$ \\
\hline Yaş (Ortt_SD) (yıl) & & $61,1 \pm 10,9$ & $58,3 \pm 13,6$ & ${ }^{*} 0,601$ \\
\hline \multicolumn{5}{|l|}{ Cinsiyet (K/E) } \\
\hline n (\%) & & $6 / 12(33,3 / 66,7)$ & $4 / 14(22,2 / 77,8)$ & $\dagger 0,711$ \\
\hline \multicolumn{5}{|l|}{ Hemipleji süresi } \\
\hline (Ort $\pm S D)$ (ay) & & $6,7 \pm 6,5$ & $6,0 \pm 5,2$ & ${ }^{*} 0,987$ \\
\hline Ağrı süresi (Ortt+SD) (ay) & & $11,7 \pm 12,3$ & $10,4 \pm 9,3$ & ${ }^{*} 0,855$ \\
\hline \multicolumn{5}{|l|}{ Eğitim Düzeyi } \\
\hline \multirow[t]{4}{*}{ n (\%) } & Okuma yazma bilmiyor & $2(11,1)$ & $6(33,3)$ & $\dagger 0,139$ \\
\hline & Illk & $15(83,3)$ & $9(50)$ & \\
\hline & Lise & $1(5,6)$ & $1(5,6)$ & \\
\hline & Üniversite & $0(0)$ & $2(11,1)$ & \\
\hline \multicolumn{5}{|l|}{ İnme tipi } \\
\hline \multirow[t]{2}{*}{ n (\%) } & İskemik & $15(83,3)$ & $17(94,4)$ & $\dagger 0,603$ \\
\hline & Hemorajik & $3(16,7)$ & $1(5,6)$ & \\
\hline \multicolumn{5}{|l|}{ Dominant tarafta lezyon } \\
\hline n (\%) & $9(50)$ & $7(38,9)$ & & $\dagger 0,738$ \\
\hline
\end{tabular}


karşılaştırılmalarında Friedman iki yönlü varyans analiz testi kullanıldı. $p<0,05$ istatistiksel olarak anlamlı düzey olarak kabul edildi.

\section{Bulgular}

Supraskapular Sinir (SSS) blokajı uygulanan 18 hastanın yaş ortalaması $61,1 \pm 10,9$ yıl, glenohumeral (GH) eklem enjeksiyonu

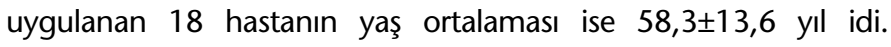
Hastaların bazı demografik ve klinik özellikleri Tablo 1 'de gösterilmiştir. Her iki gruptaki hastalar yaş $(p=0,601)$, cinsiyet $(p=0,711)$, hemipleji süreleri $(p=0,987)$, omuz ağrısı yakınma süreleri $(p=0,855)$, eğitim düzeyleri $(p=0,139)$, inme tipi $(p=0,603)$ ve dominant tarafta lezyon oranı $(p=0,738)$ açısından benzerdi.

Hastalar eşlik eden hastalıklar açısından sorgulandığında SSS blokajı uygulanan grupta 17 hastada $(\% 94,4)$ hipertansiyon, 2 hastada $(\% 11,1)$ hipertansiyon ve koroner arter hastalığı, 1 hastada $(\% 5,6)$ hipertansiyonla birlikte konjestif kalp yetmezliği ve 1 hastada $(\% 5,6)$ ise inme sonrası epilepsi öyküsü mevcuttu. $\mathrm{GH}$ eklem enjeksiyonu uygulanan grupta 14 kişide sistemik hipertansiyon (\%77,8), 1 hastada koroner arter hastalığı $(\% 5,6)$ bulunuyordu. 1 hastanın $(\% 5,6)$ inmeye neden olan veya eşlik eden hastalık öyküsü bulunmuyordu.

Hastalar ilaç kullanımı açısından sorgulandığında ise her iki gruptaki tüm hipertansif hastalar anti-hipertansif kullanıyordu. SSS grubunda 12 hasta $(\% 66,8) \mathrm{GH}$ grubunda ise 16 hasta $(\% 89,1)$ antiagregan ilaç kullanıyordu.

Hastaların kas iskelet sistemi fizik muayene bulguları tablo 2 ve 3'de gösterilmiştir. Buna göre her iki gruptaki hastaların Brunnstrom Fonksiyonel Evrelemesi (üst ekstremite, el ve alt ekstremite için) benzerdi.

Tablo 3'de belirtilen spastisite düzeyleri, "Sulkus belirtisi"nin varlığı, "Zlatkin evrelemesi", "Akromion tipi" her iki grupta benzer özellikte idi.

Her iki gruptaki hastaların enjeksiyon sonrası yapılan değerlendirmelerinde;

Tablo 4'de istirahat ağrısındaki değişmeler gösterilmiştir. Buna göre her iki grupta da tedavi sonrası- hemen, 2. hafta ve 3. ayda istirahat ağrısında anlamlı düzelme sağlandı.

Yine iki grupta hareketle ağrı ve gece ağrısında tedavi sonrasındaki dönemlerdeki değişimler Tablo $4^{\prime}$ de gösterilmiştir. Benzer şekilde 2 parametrede de 2. hafta ve 3. ayda her iki grupta anlamlı düzelmeler sağlandı.

Diğer yandan $\mathrm{GH}$ eklem enjeksiyonu ve SSS blokajı uygulanan grupların ağı durumundaki değişmeler açısından karşılaştırıımasıyla, tedavi öncesi (TÖ), tedavi sonrası (TS) 2. hafta ve TS 3. ayda ağrıdaki düzelme (istirahat, hareketle ve gece ağrısı) benzer olarak saptandı (Tablo 5). Eklem hareket açıklıklarının TÖ, TS 2. hafta ve TS 3. aydaki değerlendirmelerinde her iki grupta da anlamlı iyileşme saptandı (Tablo 6). Eklem hareket açıklığı ölçümleri gruplar karşılaştırıldıklarında da benzer olarak bulundu (Tablo 7).

Tablo 2. Bulgular-klinik özellikler-I.

\begin{tabular}{|c|c|c|c|c|c|}
\hline \multirow{2}{*}{$\begin{array}{l}\text { Brunnstrom } \\
\text { Evrelemesi } \\
\text { Üst Ekstremite }\end{array}$} & \multirow[b]{2}{*}{ Evre 1} & \multirow{2}{*}{$\begin{array}{l}\text { SSS blokaj Grubu(n=18) } \\
1(5,6)\end{array}$} & \multicolumn{2}{|c|}{ GH Enjeksiyon Grubu $(n=18)$} & \multirow[t]{7}{*}{$p^{*}$} \\
\hline & & & $2(11,1)$ & $p=0,205$ & \\
\hline \multirow[t]{5}{*}{$\mathrm{n}(\%)$} & Evre 2 & $3(16,7)$ & $9(50)$ & & \\
\hline & Evre 3 & $9(50)$ & $4(22,2)$ & & \\
\hline & Evre 4 & $4(22,2)$ & $2(11,1)$ & & \\
\hline & Evre 5 & $1(5,6)$ & $1(5,6)$ & & \\
\hline & Evre 6 & $0(0)$ & $0(0)$ & & \\
\hline $\mathrm{El}$ & Evre 1 & $2(11,1)$ & $3(16,7)$ & $p=0,178$ & \\
\hline \multirow[t]{5}{*}{$\mathrm{n}(\%)$} & Evre 2 & $3(16,7)$ & $5(27,8)$ & & \\
\hline & Evre 3 & $5(27,8)$ & $6(33,3)$ & & \\
\hline & Evre 4 & $7(38,9)$ & $1(5,6)$ & & \\
\hline & Evre 5 & $1(5,6)$ & $3(16,7)$ & & \\
\hline & Evre 6 & $0(0)$ & $0(0)$ & & \\
\hline Alt & Evre 1 & $0(0)$ & $0(0)$ & & \\
\hline Ekstremite & Evre 2 & $2(11,1)$ & $2(11,1)$ & $p=0,566$ & \\
\hline \multirow[t]{4}{*}{$\mathrm{n}(\%)$} & Evre 3 & $9(50)$ & $9(50)$ & & \\
\hline & Evre 4 & $2(11,1)$ & $5(27,8)$ & & \\
\hline & Evre 5 & $4(22,2)$ & $2(11,1)$ & & \\
\hline & Evre 6 & $1(5,6)$ & $0(0)$ & & \\
\hline
\end{tabular}


FBÖ’nün TÖ ve TS 3. aydaki değerlendirmelerinin karşılaştırılmasıyla her iki grup için istatistiksel anlamlı iyileşme saptandı. Bu parametrelerdeki iyileşme gruplar arasında benzerdi (Tablo 8).

\section{Tartışma}

Omuz ağrısı hemiplejik hastalarda yaygın ve ciddi bir problemdir. Hastaların üst ekstremite motor ve fonksiyonel gelişimini engelleyerek rehabilitasyonun başarısını olumsuz yönde etkiler. Ağrılı ve sınırlı omuz eklem hareket açıklığı günlük yaşam aktivitelerini güçleştirir, transferler ve ambulasyon sırasında dengenin güvenle sağlanmasını zorlaştırır (7,13-14).

HOA'dan korunmada uygun pozisyon ve en erken zamanda başlanan pasif EHA egzersizlerinin önemli yeri vardır. HOA tedavisi ağrı nedenine göre değişmektedir. Omuz askıları, analjezikler, NSAi ilaçlar, ISı ve buz uygulaması, çeşitli fizik tedavi ajanları, sistemik veya lokal kortikosteroid enjeksiyon uygulamaları omuz ağrısını azaltmada kullanılabilirler $(1,13,15)$. Bu tedavi yöntemlerinin birbirine üstünlüğünü gösteren yeterli sayıda randomize kontrollü çalışma bulunmamaktadır. Biz çalışmamızda HOA tedavisi için uyguladığımız supraskapular sinir blokajı ve glonehumeral eklem

\section{Tablo 3. Bulgular-klinik özellikler-ll.}

\begin{tabular}{|c|c|c|c|c|c|}
\hline \multirow{2}{*}{$\begin{array}{l}\text { Brunnstrom } \\
\text { Evrelemesi } \\
\text { Üst Ekstremite }\end{array}$} & \multirow[b]{2}{*}{ Evre 1} & \multirow{2}{*}{$\begin{array}{l}\text { SSS blokaj Grubu( } n=18) \\
1(5,6)\end{array}$} & \multicolumn{2}{|c|}{ GH Enjeksiyon Grubu $(n=18)$} & \multirow[t]{2}{*}{$p^{*}$} \\
\hline & & & $2(11,1)$ & $p=0,205$ & \\
\hline \multirow[t]{5}{*}{$\mathrm{n}(\%)$} & Evre 2 & $3(16,7)$ & $9(50)$ & & \\
\hline & Evre 3 & $9(50)$ & $4(22,2)$ & & \\
\hline & Evre 4 & $4(22,2)$ & $2(11,1)$ & & \\
\hline & Evre 5 & $1(5,6)$ & $1(5,6)$ & & \\
\hline & Evre 6 & $0(0)$ & $0(0)$ & & \\
\hline $\mathrm{El}$ & Evre 1 & $2(11,1)$ & $3(16,7)$ & $p=0,178$ & \\
\hline \multirow[t]{5}{*}{ n (\%) } & Evre 2 & $3(16,7)$ & $5(27,8)$ & & \\
\hline & Evre 3 & $5(27,8)$ & $6(33,3)$ & & \\
\hline & Evre 4 & $7(38,9)$ & $1(5,6)$ & & \\
\hline & Evre 5 & $1(5,6)$ & $3(16,7)$ & & \\
\hline & Evre 6 & $0(0)$ & $0(0)$ & & \\
\hline Alt & Evre 1 & $0(0)$ & $0(0)$ & & \\
\hline Ekstremite & Evre 2 & $2(11,1)$ & $2(11,1)$ & $p=0,566$ & \\
\hline \multirow[t]{4}{*}{ n (\%) } & Evre 3 & $9(50)$ & $9(50)$ & & \\
\hline & Evre 4 & $2(11,1)$ & $5(27,8)$ & & \\
\hline & Evre 5 & $4(22,2)$ & $2(11,1)$ & & \\
\hline & Evre 6 & $1(5,6)$ & $0(0)$ & & \\
\hline
\end{tabular}

Tablo 4. SSS blokaj ve GH eklem enjeksiyon gruplarındaki hastaların tekrarlayan ölçümlerinde gece, istirahat ve hareketle ağrıdaki değişim.

\begin{tabular}{|c|c|c|c|c|c|c|}
\hline & & $\begin{array}{l}\text { Tedavi Öncesi } \\
\text { (Ort } \pm \text { SD) }\end{array}$ & $\begin{array}{l}\text { Tedavi Sonrası } \\
\text { (Ort } \pm \text { SD) }\end{array}$ & $\begin{array}{l}\text { Tedavi Sonrası } \\
\text { 2.hafta (Ort } \pm \text { SD) }\end{array}$ & $\begin{array}{l}\text { Tedavi sonrası } \\
\text { 3.ay (Ort } \pm \text { SD) }\end{array}$ & $P^{*}$ \\
\hline SSS blokaj grubu & Gece & $55,6 \pm 27,9$ & - & $9,7 \pm 11,2$ & $12,8 \pm 15,0$ & $<0,001$ \\
\hline \multirow[t]{2}{*}{ Ağrı (VAS) (mm) } & İstirahat & $26,1 \pm 34,1$ & $16,1 \pm 25,9$ & $6,7 \pm 17,8$ & $6,7 \pm 13,3$ & $<0,001$ \\
\hline & Hareketle & $79,4 \pm 11,6$ & - & $36,7 \pm 18,5$ & $41,9 \pm 15,3$ & $<0,001$ \\
\hline GH enjeksiyon grubu & Gece & $50 \pm 28,3$ & - & $1,7 \pm 7,1$ & $4,4 \pm 13,4$ & $<0,001$ \\
\hline \multirow[t]{2}{*}{ Ağrı (VAS) (mm) } & İstirahat & $29,7 \pm 30,2$ & $25,3 \pm 26,6$ & $6,1 \pm 12,1$ & $4,4 \pm 13,4$ & $<0,001$ \\
\hline & Hareketle & $83,3 \pm 8,0$ & - & $35 \pm 18,6$ & $40,3 \pm 17,1$ & $<0,001$ \\
\hline
\end{tabular}


enjeksiyonu sonrası, her iki grupta da hem ağrı hem de omuz EHA'de anlamlı düzelme saptadık. Bu düzelme istirahat ağrısı, hareketle ağrı ve eklem hareket açıklığı parametrelerinde benzer iken, sadece gece ağrısında $\mathrm{GH}$ enjeksiyonu uygulanan grupta anlamlı olarak daha fazlaydı. Bu durum, eklem içi enjeksiyonun özellikle gece ağrısında daha etkili olduğunu göstermektedir.

Hemiplejik hastalarda omuz hareketlerindeki kısıtlılı idiyopatik ve travmatik kapsülitte gözlenen duruma benzemektedir (7). Hakuno ve ark. (16) hemiplejik hastaların etkilenen taraftaki omuzlarında artrografik olarak multipl adheziv değişiklikler saptamışlar, Ikai ve ark. (17) ise hemiplejik ağrılı omuzu olan 75 hastada ağrının esas nedenini adeziv kapsülit olarak bildirmişlerdir. $\mathrm{Bu}$ nedenle nonspesifik omuz ağrısında uygulanan ve etkinliği kanıtlanmış çeşitli enjeksiyon tekniklerinin $\mathrm{HOA}^{\prime} \mathrm{da}$ da kullanılabileceği düşünülerek bazı çalışmalar yapılmıştır. Ancak $\mathrm{HOA}^{\prime}$ da hangi enjeksiyon tekniğinin üstün olduğuna dair net bir görüş birliği bulunmamaktadır.

Yapılan retrospektif bir çalışmada Chae ve ark. (18) inme sonrası etkilenmiş tarafta omuz ağrısı olan 60 kişinin subakromial triamsinolon enjeksiyonu sonrası ağrı düzeylerinde anlamlı azalma olduğu saptanmıştır. Ancak retrospektif çalışma olmasından dolayı neden ve sonuç ilişkisinin ortaya konamaması, ayrıca hemipleji sürecinde görülen spontan iyileşmenin varlığı ya da plasebo etkisinin dışlanamaması bu çalışmanın kısıtlılıkları arasındadır.

Erçin ve ark. (19) tarafından yapılan bir çalışmada HOA'ı hastalar iki gruba ayrılmış ve bir gruba intraartiküler triamsinolon ve lokal anestezik karışımı birer hafta arayla 3 kez yapılmış, diğer gruba ise fizik tedavi uygulanmıştır. Sonuçta ağrının azalması ve omuz

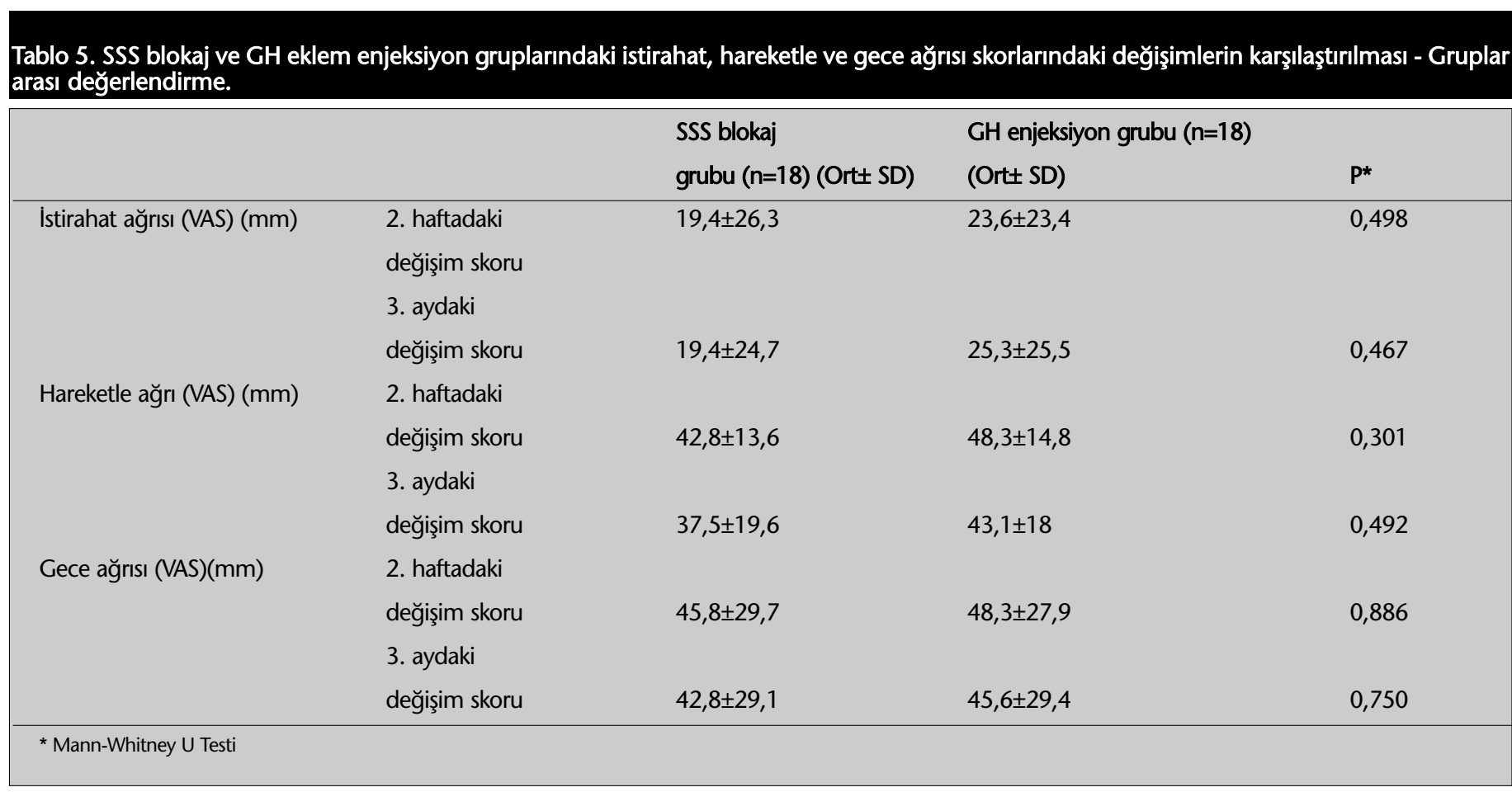

Tablo 6. SSS blokaj ve GH eklem enjeksiyon gruplarındaki hastaların tedavi sonrası eklem hareket açılığı ölçümlerindeki değişimler: Grup içi değerlendirme.

\begin{tabular}{|c|c|c|c|c|c|}
\hline & & $\begin{array}{l}\text { Tedavi öncesi } \\
\text { (Ortt SD) }\end{array}$ & $\begin{array}{l}\text { Tedavi sonrası } \\
\text { 2.hafta (Ortt SD) }\end{array}$ & $\begin{array}{l}\text { Tedavi sonrası } \\
\text { 3.ay (Ortt SD) }\end{array}$ & $p$ \\
\hline SSS blokaj grubu & Fleksiyon & $109,9 \pm 37,4$ & $128,6 \pm 19,2$ & $128,6 \pm 20,5$ & $<0,001$ \\
\hline$(n=18)$ & Abduksiyon & $109,2 \pm 27,9$ & $124,4 \pm 21,9$ & $128,9 \pm 22,9$ & $<0,001$ \\
\hline \multirow[t]{2}{*}{ EHA (derece) } & Internal rotasyon & $58,1 \pm 27,4$ & $66,9 \pm 21,4$ & $67,8 \pm 19,9$ & $<0,001$ \\
\hline & Eksternal rotasyon & $51,1 \pm 23,8$ & $59,4 \pm 18,6$ & $61,1 \pm 17,1$ & 0,009 \\
\hline GH enjeksiyon & Fleksiyon & $108,6 \pm 23,6$ & $129,4 \pm 14,6$ & $131,7 \pm 15,2$ & $<0,001$ \\
\hline grubu $(n=18)$ & Abduksiyon & $105,6 \pm 22,5$ & $125,8 \pm 19,6$ & $125,8 \pm 17,6$ & $<0,001$ \\
\hline \multirow[t]{2}{*}{ EHA (derece) } & Internal rotasyon & $68,1 \pm 13,8$ & $78,9 \pm 8,3$ & $80 \pm 8,4$ & $<0,001$ \\
\hline & Eksternal rotasyon & $50,6 \pm 20,6$ & $59,4 \pm 16,3$ & $62,2 \pm 16,3$ & $<0,001$ \\
\hline
\end{tabular}


Tablo 7. SSS blokaj ve GH eklem enjeksiyon gruplarındaki hastaların tedavi sonrası eklem hareket açıklığındaki değişimler: Gruplar aras değerlendirme.

\begin{tabular}{|c|c|c|c|c|}
\hline & & $\begin{array}{l}\text { SSS blokaj } \\
\text { Grubu ( } n=18)(\text { Ortt SD) }\end{array}$ & $\begin{array}{l}\text { GH Enjeksiyon Grubu } \\
(n=18)(\text { Ort } \pm S D)\end{array}$ & $\mathrm{p}$ \\
\hline \multirow[t]{2}{*}{ Fleksiyon } & 2. haftadaki değişim skoru & $18,7 \pm 24,9$ & $20,8 \pm 16$ & 0,265 \\
\hline & 3. aydaki değişim skoru & $18,7 \pm 24,3$ & $23,1 \pm 16,6$ & 0,125 \\
\hline \multirow[t]{2}{*}{ Abdüksiyon } & 2. haftadaki değişim skoru & $15,3 \pm 14,4$ & $20,3 \pm 14,9$ & 0,238 \\
\hline & 3. aydaki değişim skoru & $19,7 \pm 17,1$ & $20,3 \pm 14$ & 0,632 \\
\hline \multirow[t]{2}{*}{ Internal rotasyon } & 2. haftadaki değişim skoru & $8,9 \pm 8,5$ & $10,8 \pm 11,4$ & 0,803 \\
\hline & 3. aydaki değişim skoru & $9,7 \pm 10,6$ & $11,9 \pm 10,7$ & 0,653 \\
\hline \multirow[t]{2}{*}{ Eksternal rotasyon } & 2. haftadaki değişim skoru & $8,3 \pm 10,8$ & $8,9 \pm 9$ & 0,582 \\
\hline & 3. aydaki Değişim Skoru & $10 \pm 17,2$ & $11,7 \pm 10,3$ & 0,446 \\
\hline
\end{tabular}

Table 8. SSS blokaj ve GH eklem enjeksiyon gruplarındaki hastaların tedav öncesi ve tedavi sonrası 3. aydaki Fonksiyonel Bağımsızlı Ölçeği skorlarının dağlımı.

\begin{tabular}{llll} 
& Tedavi öncesi & Tedavi sonrası 3.ay & P* \\
\hline $\begin{array}{l}\text { SSS Blokaj } \\
\text { Grubu-FBÖ }\end{array}$ & $101,3 \pm 15,1$ & $103,3 \pm 14,2$ & 0,005 \\
$\begin{array}{l}\text { GH Enjeksiyon } \\
\text { Grubu-FBÖ }\end{array}$ & $98,8 \pm 13,1$ & $104,4 \pm 9,3$ & 0,003 \\
p† & 0,646 & 0,776 & \\
\hline $\begin{array}{l}\text { *Wilcoxon Signed Ranks Test } \\
\text { †Mann-Whitney U Test }\end{array}$ & \\
FBÖ: Fonksiyonel bağımsızlık ölçeği &
\end{tabular}

EHA'da artış enjeksiyon grubunda daha anlamlı bulunmuştur.

Dekker ve ark. (7) yedi hemiplejik omuz ağrilı hastaya 3 kez intraartiküler olarak 40 mg triamsinolon enjeksiyonu uygulamışlar ve omuz ağrısını azaltmada etkin olduğunu göstermişlerdir. Güngör ve ark. (20) tarafından 10 hemiplejik hastaya uygulanan intraartiküler triamsinolon asetonid enjeksiyonu sonrası 2 . haftadan itibaren ağrı düzeylerinde anlamlı azalma ve 2 . haftadan itibaren eklem hareket açıklıklarında anlamlı ölçüde iyileşme saptamışlardır. Ancak kontrol grubu olmayan bu iki çalışmanın olgu sayıları da yetersizdir. Snels ve ark. (5) yaptığı plasebo kontrollü bir çalışmada (5) ise $\mathrm{HOA}^{\prime}$ ı 37 hastada uygulanan intraartiküler triamsinolon asetonid enjeksiyonunun plaseboya üstün olmadığını saptamışlardır. Bizim çalışmamızda intraartiküler triamsinolon asetonid uygulanan hastalarda tedavi öncesine göre tedavi sonrası 3. aya kadar devam eden anlamlı iyileşme gözlemledik. Her ne kadar plasebo etkisini ekarte edemesek de çalışmamızda glenohumeral eklem enjeksiyonunun etkin olduğunu söyleyebiliriz.

Supraskapular sinir blokajı ise romatoid artrit, donuk omuz ve rotator manşon lezyonlarında ağrıyı ortadan kaldırmak amacıyla kullanılmaktadır. Ancak HOA'da etkinliğini araştıran literatürde az sayıda çalışma vardır. Lee ve ark. (6) HOA'lı sadece 3 hastada uyguladıkları SSS blokajının hastaların ağrılarında tam bir iyileşme sağlamadığını bildirmişlerdir. Hemiplejik ağrılı omuz tedavisinde çalışmamıza benzer bir çalışmayı Özturan ve ark. (21) yapmışlardır. Ancak burada çalışmamızdan farklı olarak bir gruba SSS blokajı $(n=20)$ diğer gruba da periartiküler omuz enjeksiyonu $(n=23)$ uygulanmış, ağrı ve EHA'da iyileşme açısından SSS blokajı daha yararlı bulunmuştur. HOA'na sebep olan multifaktöryel etiyolojik etmenler göz önüne alındığında periartiküler enjeksiyonların tek başına yetersiz kalabileceği, bundan dolayı SSS blokajının daha etkin bulunmuş olabileceğini düşünmekteyiz.

Son zamanlarda yapılmış bir diğer çalışmada hemiplejik omuz ağrısında intraartiküler steroid enjeksiyonu ve supraskapular sinir blokajı karşılaştırılmış, bizim çalışmamızla benzer olarak her iki tedavi seçeneğinin etkin ancak birbirine üstün olmadığı ortaya konulmuştur (8).

Diğer yandan nonspesifik omuz ağrılı toplam 60 hastada Taşkaynatan ve ark. (22) supraskapular sinir blokajı ve steroid enjeksiyonunun etkinliklerini karşılaştırmışlardır. Steroid enjeksiyonunun bisipital oluk ve subakromial aralık olmak üzere 2 noktadan uygulandığı ve SSS blokajında yalnızca lokal anestezik madde kullanıldığı bu çalışmada enjeksiyonların etkinliklerinin benzer olduğu sonucuna varılmıştır. Bu çalışma sonucuna göre Taşkaynatan ve ark. (22), SSS blokajını daha az komplikasyona yol açması ve etkin olması nedeniyle önermektedirler. Biz çalışmamızda istirahat, gece ve hareket sırasındaki ağrı yanında eklem hareket açıklıklarında her iki enjeksiyon tipinin etkin ancak birbirine üstün olmadıklarını gösterdik.

HOA'da tedavi amacıyla uygulanan, yukarıda bahsedilen çalışmalarda enjeksiyonların etkinliği genellikle EHA ve ağrı üzerinden değerlendirilmiştir. Güngör ve ark. (20) yaptığı çalışmada motor fonksiyon Fugl Meyer İndeksi ile, üst ekstremite motor fonksiyonu ise Action Research Arm testi (ARA) ile değerlendirilmiş. Fugl Meyer indeksinde anlamlı düzelme saptanırken, ARA'da anlamlı düzelme bulunamamıştır. Snels ve ark. (5) başta olmak üzere bazı araştırmacılar pasif dış rotasyon ölçümlerinin önemli olduğunu belirtmektedirler. Ancak Snels ve ark. (5) bu parametre üzerinden yaptıkları çalışmada anlamlı 
iyileşmenin olmadığı sonucuna varmışlardır. Hemiplejik olmayan hastalarda omuz fonksiyonları çeşitli parametrelerle değerlendirilebilir. Ancak HOA'da bunların standardize edilmeleri gerekmektedir. Çünkü hemiplejide aktif katılımın olmadığı hastalarda fonksiyonel değerlendirme için bu parametrelerin uygulanması sorun yaratmaktadır ve hastalar arası ve çalışmayı yapanlar arasında standardizasyonun sağlanmasını güçleştirmektedir. Hastaların özürlülük durumlarının değerlendirmede FBÖ’yü kullandık. FBÖ sonuçlarına göre; her iki enjeksiyon yönteminde de ağrıda azalma ve $E H A^{\prime}$ da artışa paralel bir fonksiyonel iyileşme sağlanmaktadır. Ancak hastaların çoğunun erken dönem (ilk 1 yıl) içinde olmaları fonksiyonel iyileşmeye katkıda bulunmuş olabilir.

Çalışmamızın en önemli kısıtıı̆ı̆ı, iki gruptaki vaka sayısının yetersiz olması ve uzun dönem sonuçlarının olmamasıdır. Enjeksiyon tedavilerinin etkinliğini daha iyi değerlendirmek için, daha fazla sayıda, uzun dönem takipli randomize kontrollü çalışmalara intiyaç olduğu kanaatindeyiz.

Sonuç olarak her iki enjeksiyon yöntemi de kolay uygulama, düşük maliyet, hospitalizasyon gerektirmeme, hızlı tedavi olanağı sağlama avantajıyla, hemiplejik omuz ağrısında yararlı görünmektedir. Özellikle hastalardaki mevcut gece ağrısını $\mathrm{GH}$ eklem enjeksiyonu daha iyi kontrol etmektedir. Bunun dışında her iki enjeksiyon yönteminin birbirine üstünlüğü yoktur. Hastalardaki mevcut omuz ağrısının rehabilitasyon sürecini olumsuz etkilemesi nedeniyle rehabilitasyon programının başında hastanın HOA açısından iyi değerlendirilmesi ve HOA'nın tedavi edilmesi gerekmektedir. Bundan dolayı rehabilitasyon sürecini hızlandırmak amacıyla gerekli olgularda uygulanmasının faydalı olacağını düşünmekteyiz.

\section{Çıkar Çatışması:}

Yazarlar herhangi bir çıkar çatışması bildirmemişlerdir.

\section{Kaynaklar}

1. Snels IA, Beckerman $H$, Lankhorst G], Bouter LM. Treatment of hemiplegic shoulder pain in the Netherlands: results of a national survey. Clin Rehabil 2000;14:20-7.

2. Peker Ö, Gündüz B. Hemiplejik omuz ağrısı. Ege Fiz Tıp Reh Der 1997;3:213-6.
3. Aras MD, Çakcı A. Inme rehabilitasyonu. Içinde: Oğuz H, Dursun $E$, Dursun N. editörler. Tıbbi rehabilitasyon. Istanbul: Nobel Tıp Kitapevi; 2004. s. 589-617.

4. Kumar R, Metter EJ, Mehta AJ, Chew T. Shoulder pain in hemiplegia. Am J Phys Med Rehabil 1990;69:205-8.

5. Snels IA, Beckerman H, Twisk JV, Dekker JH, Koning PD, Koppe PA, et al. Effect of Triamcinolone Acetonide Injections on Hemiplegic Shoulder Pain A Randomized Clinical Trial. Stroke 2000;31:2396-401.

6. Lee $\mathrm{KH}$, Khunadorn $\mathrm{F}$. Painful shoulder in hemiplegic patients: a study of the suprascapular nerve. Arch Phys Med Rehab 1986;67:818-20.

7. Dekker JH, Wagenaar RC, Lankhorst G], de Jong BA. The painful hemiplegic shoulder: effects of intra-articular triamcinolon acetonide. Am J Phys Med Rehabil 1997;76:43-8.

8. Yasar E, Vural D, Safaz I, Balaban B, Yilmaz B, Goktepe AS, et al. Which treatment approach is better for hemiplegic shoulder pain in stroke patients: intra-articular steroid or suprascapular nerve block? A randomized controlled trial. Clin Rehabil 2011;25:60-8.

9. Zlatkin MB, lannotti JP, Roberts MC, Esterhai JL, Dalinka MK, Kressel HY, et al. Rotator cuff tears: Diagnostic performance of MRG imaging. Radiology 1989;172:223-9.

10. Bigliani LU, Morison DS, April EW. The morphology of the acromion and its relationship to rotator cuff tears. Orthop Trans 1986;10:216.

11. Shanahan EM, Ahern $M$, Smith $M$, Wetherall $M$, Bresnihan B, FitzGerald O. Suprascapular nerve block (using bupivacaine and methylprednisolone acetate) in chronic shoulder pain. Ann Rheum Dis 2003;62:400-6.

12. Küçükdeveci AA, Yavuzer $G$, Elhan AH, Sonel B, Tennant A. Adaptation of the functional independence measure for use in Turkey. Clin Rehabil 2001;15:311-9.

13. Griffin JW. Hemiplegic shoulder pain. Phys Ther 1986;66:1884-93.

14. Joynt RL. The source of shoulder pain in hemiplegia. Arch Phys Med Rehabil 1992;73:409-13.

15. Bruton JD. Shoulder pain in stroke patients with hemiplegia or hemiparesis following a cerebrovascular accident. Physiotherapy 1985;71:2-4.

16. Hakuno A, Sashika $H$, Ohkawa $T$, Itoh R. Artrographic findings in hemiplegic shoulders. Arch Phys Med Rehabil 1984;65:706-11.

17. Ikai T, Tei K, Yoshida K, Miyano S, Yonemoto K. Evaluation and treatment of shoulder subluxation in hemiplegia: Relationship between subluxation and pain. Am J Phys Med Rehabil 1998;77:421-6.

18. Chae J, Jedlicka L. Subacromial corticosteroid injection for poststroke shoulder pain: an exploratory prospective case series. Arch Phys Med Rehabil 2009;90:501-6.

19. Erçin $O$, Tezyürek $M$, Karagöz A, Özgirgin N. Hemiplejik ağrılı omuz tedavisinde intraartiküler enjeksiyon ile fizik tedavinin etkinliklerinin karşılaştıııması. Fiziksel Tıp 2000;3:117-20.

20. Güngör $M$, Demir $M$, Tomruk $S$, Çakcı $A$. Hemiplejik ağrılı omuzda triamsinolon asetonid'in etkinliği. Fiziksel Tıp 2000;3:125-30.

21. Özturan BT, Yavuz N, Akyüz M, Okçu M. Supraskapular sinir blokajı veya periartiküler omuz enjeksiyonu: Hangisi hemiplejik ağrılı omuzun tedavisinde daha etkilidir? Romatizma 1996;11:179-83.

22. Taskaynatan MA, Yilmaz B, Ozgul A, Yazicioglu K, Kalyon TA. Supraskapular nevre block versus steroid injection for non-spesific shoulder pain. Tohoku J Exp Med 2005;205:19-25. 